\title{
Oncoprotein HCCR-I expression in breast cancer is well correlated with known breast cancer prognostic factors including the HER2 overexpression, p53 mutation, and ER/PR status
} Seon-Ah Ha ${ }^{\dagger 1}$, Youn Soo Lee ${ }^{\dagger 2}$, Seung Min Shin ${ }^{1}$, Hyun Kee Kim¹, Sanghee Kim¹, Hong Namkoong1, Hae Joo Kim¹, Sang Min Jung1, Yu Sun Lee ${ }^{1}$, Yeun Jun Chung ${ }^{3}$, Sang Seol Jung ${ }^{4}$ and Jin Woo Kim*1,5

\begin{abstract}
Address: ${ }^{1}$ Department of Molecular Genetic Laboratory, College of Medicine, The Catholic University of Korea, Seoul 137-040, Korea, ${ }^{2}$ Department of Hospital pathology, College of Medicine, The Catholic University of Korea, Seoul 137-040, Korea, ${ }^{3}$ Department of Microbiology, College of Medicine, The Catholic University of Korea, Seoul 137-040, Korea, ${ }^{4}$ Department of Surgery, College of Medicine, The Catholic University of Korea, Seoul 137-040, Korea and 5Department of Obstetrics and Gynecology, College of Medicine, The Catholic University of Korea, Seoul 137-040, Korea

Email: Seon-Ah Ha - hsa387@hanmail.net; Youn Soo Lee - lys9908@catholic.ac.kr; Seung Min Shin - bleukid@hanmail.net; Hyun Kee Kim - scotlandpapa@msn.com; Sanghee Kim - angelsanghee@yahoo.com; Hong Namkoong - nkhong1@hanmail.net; Hae Joo Kim - jinwoo@catholic.ac.kr; Sang Min Jung - jsmin1257@hanmail.net; Yu Sun Lee - jinwoo@catholic.ac.kr; Yeun Jun Chung - yejun@catholic.ac.kr; Sang Seol Jung - jinwoo@catholic.ac.kr; Jin Woo Kim* - jinwoo@catholic.ac.kr

* Corresponding author †Equal contributors
\end{abstract}

Published: II February 2009

BMC Cancer 2009, 9:5। doi:|0.||86/|47|-2407-9-5|
Received: 17 March 2008

Accepted: II February 2009

This article is available from: http://www.biomedcentral.com/I47I-2407/9/5 I

(C) $2009 \mathrm{Ha}$ et al; licensee BioMed Central Ltd.

This is an Open Access article distributed under the terms of the Creative Commons Attribution License (http://creativecommons.org/licenses/by/2.0), which permits unrestricted use, distribution, and reproduction in any medium, provided the original work is properly cited.

\begin{abstract}
Background: Oncoprotein HCCR-I functions as a negative regulator of the p53 and contributes breast tumorigenesis. The serum HCCR-I assay is useful in diagnosing breast cancer and mice transgenic for HCCR developed breast cancers. But it is unknown how HCCR-I contributes to human breast tumorigenesis.
\end{abstract}

Methods: Oncogene HCCR-I expression levels were determined in normal breast tissues, breast cancer tissues and cancer cell lines. We examined whether HCCR-I protein expression in breast cancer is related to different biological characteristics, including ER, PR, P53 genotype, and HER2 status in 104 primary breast cancer tissues using immunohistochemical analyses.

Results: HCCR-I was upregulated in breast cancer cells and tissues compared with normal breast tissues. In this study, overexpression of HCCR-I was well correlated with known breast cancer prognostic markers including the presence of steroid receptors (ER and PR), p53 mutation and high HER2 overexpression. HCCR-I was not detected in the ER-negative, PR-negative, p53 negative and low HER2 breast cancer tissues. These data indicate that the level of HCCR-I in breast cancer tissues is relatively well correlated with known breast cancer factors, including the HER2 overexpression, p53 mutation, and ER/PR status.

Conclusion: Determination of HCCR-I levels as options for HER2 testing is promising although it needs further evaluation. 


\section{Introduction}

Cells expressing HCCR-1 are tumorigenic in nude mice [1]. The functional role of this oncogene in tumorigenesis is manifested as a negative regulator of the 533 tumor suppressor [1]. In the previous study, we investigated HCCR1 protein expression in breast cancer and the possibility of using HCCR-1 as a useful biomarker for human breast cancer [2]. We also examined whether HCCR-1 protein expression in breast cancer is related to different biological characteristics including ER, PR, p53 genotype, and the HER2 status. Northern and Western blot analyses and immunohistochemical studies indicate that the HCCR-1 mRNA and protein are overexpressed in breast cancer tissues compared to the normal breast tissues $[1,2]$. Serological studies revealed an $86.8 \%$ sensitivity for HCCR-1 in breast cancer, which was higher than $21.0 \%$ for CA15-3 $[2,3]$. The HCCR-1 assay has an advantage over CA15-3 in diagnosing breast cancer. These results indicate that HCCR-1 is an oncoprotein that is related to breast cancer development $[1,2]$.

Overexpression of human epidermal growth factor receptor type 2 (HER2, also referred to as HER2/neu or ErbB-2), a $185-\mathrm{kD}$ receptor first described more than two decades ago [4], occurs in 20 to $30 \%$ of invasive breast cancers. In general, patients with breast-cancer cells that overexpress this receptor or that have a high copy number of its gene have decreased overall survival and may have differential responses to a variety of chemotherapeutic and hormonal agents $[5,6]$. Thus, strategies to target HER2 appear to be important in treating breast cancer [7]. HER2 signaling promotes cell proliferation through the RAS-MAPK pathway and inhibits cell death through the phosphatidylinositol 3'-kinase-AKT-mammalian target of rapamycin (mTOR) pathway [8]. Likewise, the HCCR-1 signaling is also known to be regulated by the phosphatidylinositol 3'-kinase-AKT pathway [9].

According to our previous study using a panel of breast cancer cell lines [2], HCCR-1 was highly expressed in breast cancer cell lines with high HER2 overexpression, with some exceptions, that have a mutated p53 and express ER/PR [10-13]. These data indicate that the HCCR-1 overexpression in breast cancer cell lines is well correlated with known breast cancer prognostic markers including high HER2 overexpression [10-13].

Because HER2 overexpression and amplification have important consequences on the prognosis and treatment of breast cancer, their presence must be accurately determined. Currently, two different methods are being used worldwide, immunohistochemistry (IHC) and fluorescence in situ hybridization (FISH). These two techniques identify different targets and both have advantages and disadvantages [14]. Which method should be viewed as the gold standard for HER2 determination remains a debate. Recently, other methods have been described as options for HER2 testing. Real time polymerase chain reaction (RT-PCR) [15] and chromogen in situ hybridization (CISH) [16] have been proposed as cheaper and easier alternatives to FISH. Acceptable correlations between both methods and FISH have been reported [14]. But the correlations among the various clinical methods of detecting HER2 are imperfect with regard to both prognostication and the prediction of a response to trastuzumab (Herceptin, Genentech).

Multiple studies have demonstrated marked improvement in disease-free and overall survival when trastuzumab is incorporated in therapeutic regimens for HER2 overexpressed tumors $[17,18]$. Only patients whose tumors strongly overexpress HER2 by immunohistochemistry (IHC) and/or have amplification of the cerb2 gene by FISH, are likely to respond to Herceptin treatment [19].

Testing invasive breast carcinomas for HER2 overexpression/gene amplification has become a standard of practice [20]. Much of the recent literature has focused on the best method for documenting HER2 overexpression (IHC vs. FISH), technical limitations of each method, and the need for consistency and QA in test performance [17,21-23]. The National Comprehensive Cancer Network HER2 Testing in Breast Cancer Task Force concluded that where adequate quality control/quality assurance procedures are followed, either IHC or FISH are acceptable methods [24].

Whether a laboratory uses IHC with FISH for equivocal cases, or uses FISH as the initial HER2 screen, these tests are expensive to perform. Development of a rational approach to selecting cases for HER2 testing would promote cost effectiveness in the health care system [25].

The aim of this study is to analyze the level of HCCR-1 expression in breast cancer tissues in order to demonstrate its correlation to other biomarkers including ER, PR, p53, and HER2, and estimate the possibility of HCCR-1 as a new biomarker candidate for breast cancer.

\section{Methods \\ Tissues and cell lines}

Human normal and cancer tissues were obtained during operation. All patients were subjected to the analysis with individual consent for the study. The use of tissue samples was approved by the Ethics Committee of our institution (Kangnam St. Mary's Hospital, Seoul, Korea). Mammalian cell lines were obtained from the American Type Culture Collection (ATCC; Manassas, VA). BT-474, MCF-7 and MDA-MB-231 are human breast carcinoma cell lines from mammary gland. MCF7 and MDA-MB-231 cells express 
low HER2, and BT-474 cells express high HER2. BT-474 and MCF-7 cells are ER-positive and PR-positive cells. MDA-MB-231 is ER-negative and PR-negative cell line. MCF-7 cells have wild type p53, and MDA-MB-231 and BT-474 cells have mutated p53.

\section{Northern blot analysis}

Total RNA was extracted from fresh human tissues and cell lines using RNeasy total RNA kit (Qiagen). Northern blot analysis was carried out, in which $20 \mu \mathrm{g}$ of denatured total RNA was electrophoresed on a $1.0 \%$ formaldehyde agarose gel and transferred to nylon membrane. Human $\beta$ actin cDNA control probe was used as a loading control. All blots were hybridized with the randomly primed [ $\left.{ }^{32} \mathrm{P}\right]-$ labeled HCCR-1 partial cDNA probe.

Immunohistochemical analysis and staining interpretation For immunohistochemistry experiments, paraffin sections ( $5-\mu \mathrm{m}$ thick) of normal human breast and cancer tissues were used for stainings using monoclonal antibodies against ER, PR, and p53, and affinity-purified polyclonal anti-HCCR-1 antibodies. Endogenous peroxide and nonspecific binding were blocked by using 3\% hydrogen peroxide in TBST and with TBST diluted 1:10 in FBS for 30 minutes, respectively. Then sections were incubated with primary antibodies (diluted in TBST-FBS solution) for 2 hours at room temperature. Corresponding negative controls were incubated in the absence of primary antibody. Aminoethyl carbozole (AEC) was used as the chromogen. After immunostaining, sections were counterstained with hematoxylin. Representative examples of stained tissues were photographed under the microscope. Pathologist counted at least 500 tumor cells in the area most strongly stained for ER, PR and p53. Positive staining for ER, PR, and p53 was defined by nuclear staining. According to most accepted cut-off point, $10 \%$ positive staining of tumor cells was used as positive result for ER, PR and p53. Immunohistochemically detected p53 protein is mutated p53 protein due to its prolonged half-life. The positive staining of tumor cells is strongly correlated with p53 mutation [26]. The HER2 immunohistochemical staining results were interpreted according to staining criteria. Positive staining for HER2 was defined by membrane staining. Cytoplasmic staining was not considered positive. Tumor cells showing no immunoreactivity (score 0) or the incomplete and faint membrane staining (score 1+) were considered as negative. HER2 was defined as positive when the complete weak to moderate membrane staining (weakly positive; score $2+$ ) or the complete strong membrane staining (strongly positive; score $3+$ ) was observed in more than $10 \%$ of tumor cells. The HCCR-1 immunohistochemical staining results was defined by cytoplasmic staining. The cut-off point of HCCR-1 for positive and negative staining was used $0 \%$ of cells. We changed
HCCR-1 staining results as positive and negative results instead of stability.

\section{Results and discussion}

\section{Overexpression of HCCR-I in breast cancers}

We examined the expression patterns of HCCR-1 in human normal tissues, cancer tissues and cell lines. Northern blot analysis revealed an increased expression of HCCR-1 in fresh primary human breast cancer tissues compared to their normal counterparts (Fig. 1). HCCR-1 was abundantly detected in BT-474 (ER+/PR+/mutant p53/HER2 3+) and MCF-7 (ER+/PR+/wild p53/HER2 -) cells whereas it was not detected in MDA-MB-231 (ER-/ PR-/mutant p53/HER2 -) cells (Fig. 1). The expression level of HCCR-1 was higher in BT-474 than in MCF-7.

\section{HCCR-I is well correlated with known breast cancer prognostic parameters}

We conducted the following experiment to investigate whether the results of our previous study in which breast cancer cell lines were used [2] can be replicated in this study using fresh primary breast cancer tissues. The expression of HCCR-1 was measured in a panel of fresh 104 primary breast cancer tissues and their normal counterparts (Table 1 and Fig. 2). The increasing expression level of HCCR-1 was observed in the order of breast cancer tissues with $(\mathrm{ER}+/ \mathrm{PR}+/$ mutant p53/HER 3+), (ER+/PR+/ wild p53/HER2 2+), and (ER+/PR+/wild p53/HER2 -). HCCR-1 was not detected in breast cancer tissues with (ER-/PR-/p53-/low HER2) (Table 1 and Fig. 2). These results confirm our previous findings in breast cancer cell lines in that HCCR-1 expression is correlated with known prognostic markers for breast cancer.

Since HER2 overexpression/amplification has important consequences on the prognosis and treatment of breast

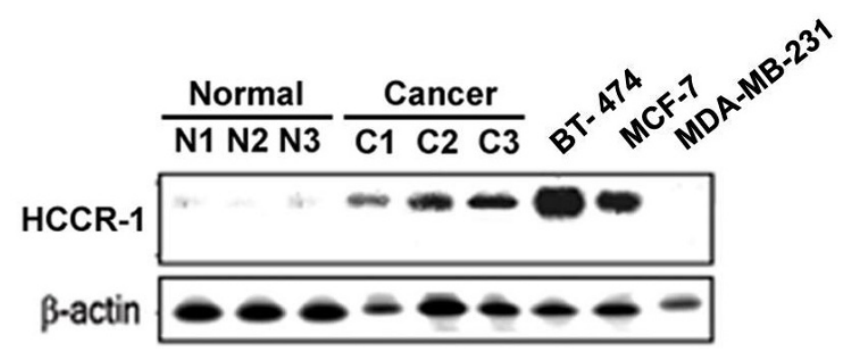

Figure I

HCCR-I expressions in breast cancers. Northern analyses of HCCR-I in human breast tissues and cell lines. Comparison of HCCR-I mRNA expressions in breast cancer cell lines (BT-474, MCF-7 and MDA-MB-23I), and fresh primary breast cancer tissues $(C)$ and their corresponding normal counterparts $(\mathrm{N})$. Human $\beta$-actin cDNA was used as a control probe (bottom panel). 
Table I: Correlation of the HCCR-I expression levels in 104 primary breast cancer tissues with known breast cancer prognostic parameters including the ER/PR expression, p53 status and HER2 overexpression

\begin{tabular}{lccccc}
\hline $\begin{array}{l}\text { No. of } \\
\text { Cancer tissues }\end{array}$ & $\begin{array}{c}\text { ER } \\
\text { status }\end{array}$ & $\begin{array}{c}\text { PR } \\
\text { status }\end{array}$ & $\begin{array}{c}\text { P53 } \\
\text { status }\end{array}$ & $\begin{array}{c}\text { HER2 } \\
\text { Over-expression }\end{array}$ & $\begin{array}{c}\text { HCCR-I } \\
\text { expression }\end{array}$ \\
\hline 30 & positive & positive & mutant & strong positive & positive \\
23 & positive & positive & wild & moderate positive & positive \\
23 & positive & positive & wild & negative & positive \\
28 & negative & negative & null & negative & \\
\hline
\end{tabular}

All the breast cancer tissues were derived from pathologically-proven invasive ductal carcinomas.

cancer $[10,13]$, its presence should be precisely determined. However, the various clinical methods of detecting HER2 are not perfect with regard to both prognostication and the prediction of a response to trastuzumab [14,27-29]. HER2 testing continues to evolve, and many clinical laboratories currently use both tests (IHC and FISH). An efficient testing strategy consists of immunostaining followed by FISH in tumors with $2+$ staining intensity [29]. This approach should minimize the risks of not treating patients who might benefit from trastuzumab and of treating patients who are unlikely to have a response; this is a critically important distinction as the use of trastuzumab moves into the adjuvant setting [7].
Reported adjuvant trials used centralized laboratory review because of the high rate of discordant interpretations among individual laboratories [30,31].

Our data reveal that the HCCR-1 expression is tightly associated with HER2 activity in breast cancer tissues. This implies that the prognosis for the breast cancer might be improved when combining the measurement of the HCCR-1 level and the HER2 activity.

\section{Conclusion}

Our results highlight the strong correlation of HCCR-1 expression in breast cancer to other prognostic factors and
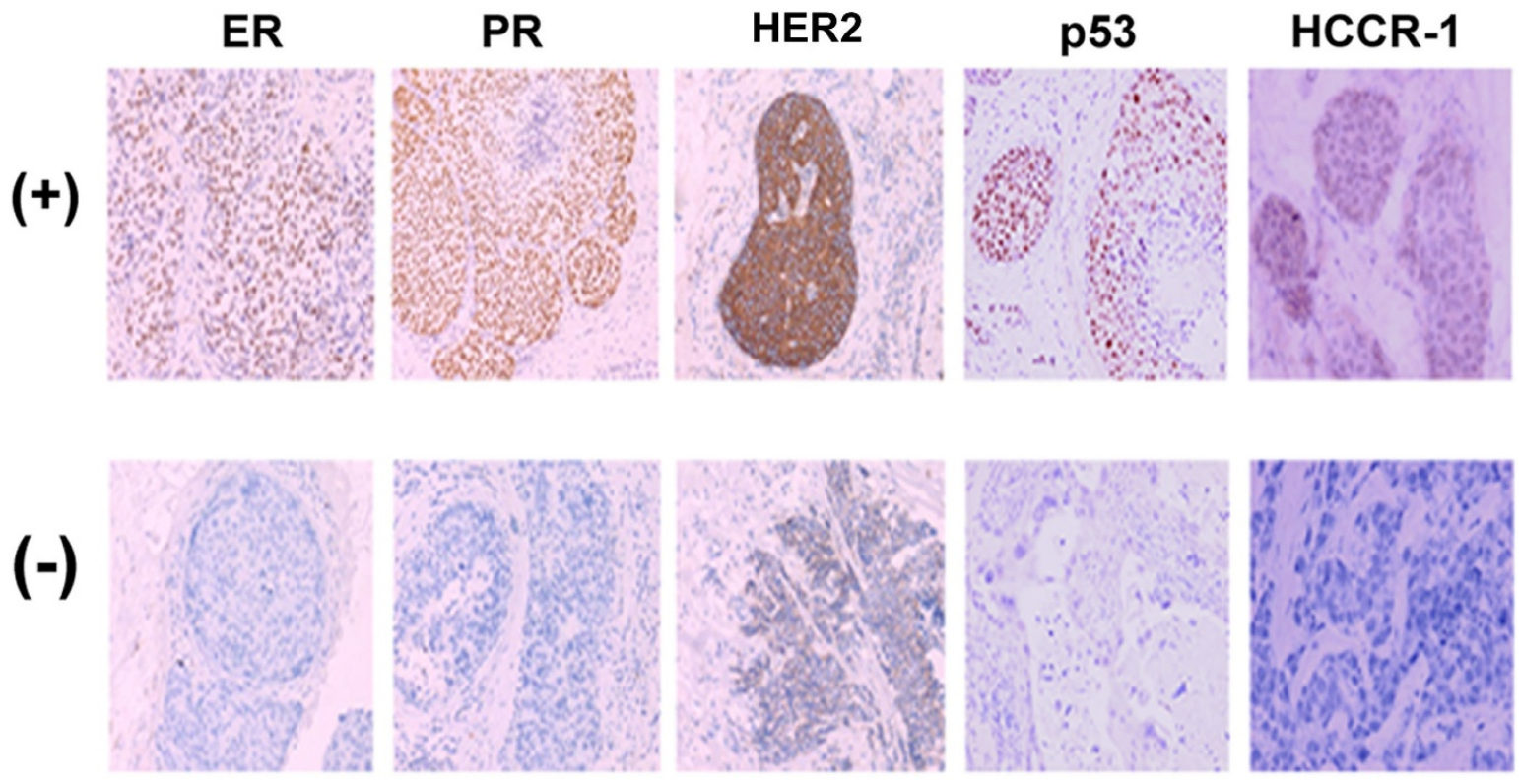

\section{Figure 2}

HCCR-I is positively well correlated with breast cancer prognostic parameters. Correlation of HCCR-I expression levels with known breast cancer prognostic parameters. Immunohistochemical staining for ER, PR, HER2, p53 and HCCR$\mathrm{I}$ in fresh frozen tissues from human breast cancers. All the breast cancer tissues were derived from pathologically-proven invasive ductal carcinomas. Positive immunostaining for ER, PR, and p53 in the nuclei of carcinoma cells and for HCCR-I in the cytoplasm of carcinoma cells (top panel). The HER2 immunohistochemical staining showing complete strong membrane staining (3+) in the carcinoma cells (top panel). Negative immunostaining for ER, PR, P53, HER2 and HCCR-I in breast carcinoma (bottom panel). Original magnification, $\times 100$. 
raise the possibility that HCCR-1 expression can be used as a new prognostic marker for breast cancer.

\section{Competing interests}

The authors declare that they have no competing interests.

\section{Authors' contributions}

SA was the principal investigator of this study. SMS performed the laboratory assays. KHK, SH and HN contributed to the data/sample collection. YSL interpreted staining results. HJK, SMJ and YSL contributed to study design. YJC, SSJ and JWK critically reviewed and wrote the manuscript. All authors read and approved the final manuscript.

\section{Acknowledgements}

This work was supported by 'Seoul R\&BD program', 2006.

\section{References}

I. Ko J, Lee YH, Hwang SY, Lee YS, Shin SM, Hwang JH, Kim J, Kim YW, Jang SW, Ryoo ZY, Kim IK, Namkoong SE, Kim JW: Identification and differential expression of novel human cervical cancer oncogene HCCR-2 in human cancers and its involvement in p53 stabilization. Oncogene 2003, 22:4679-4689.

2. Jung SS, Park HS, Lee IJ, Namkoong H, Shin SM, Cho GW, Ha SA, Park YG, Lee YS, Ko J, Kim JW: The HCCR oncoprotein as a biomarker for human breast cancer. Clin Can Res 2005, I I:7700-7708.

3. Lamerz R, Stieber P, Fateh-Moghadam A: Serum marker combinations in human breast cancer (review). In Vivo 1993, 7(6B):607-613.

4. Schechter AL, Stern DF, Vaidyanathan L, Decker SJ, Drebin JA, Greene MI, Weinberg RA: The neu oncogene: an erb-B-related gene encoding a 185,000-Mr tumour antigen. Nature 1984, 3। 2:513-516.

5. Ellis MJ, Coop A, Singh $B$, Mauriac L, Llombert-Cussac $A$, Jänicke $F$, Miller WR, Evans DB, Dugan M, Brady C, Quebe-Fehling E, Borgs M: Letrozole is more effective neoadjuvant endocrine therapy than tamoxifen for ErbB-I- and/or ErbB-2-positive, estrogen receptor-positive primary breast cancer: evidence from a phase III randomized trial. J Clin Oncol 200I, 19:3808-38I6.

6. Ménard S, Valagussa P, Pilotti S, Gianni L, Biganzoli E, Boracchi P, Tomasic G, Casalini P, Marubini E, Colnaghi MI, Cascinelli N, Bonadonna G: Response to cyclophosphamide, methotrexate, and fluorouracil in lymph node-positive breast cancer according to HER2 overexpression and other tumor biologic variables. I Clin Oncol 200I, 19:329-335.

7. Hudis CA: Trastuzumab-Mechanism of action and use in clinical practice. N Engl J Med 2007, 357:39-5I.

8. Yarden Y, Sliwkowski MX: Untangling the ErbB signalling network. Nat Rev Mol Cell Biol 200I, 2:127-I37.

9. Cho GW, Shin SM, Namkoong H, Kim HK, Ha SA, Hur SY, Kim TE, Chai YG, Kim JW: The phosphatidylinositol 3-kinase/Akt pathway regulates the HCCR-I oncogene expression. Gene 2006, 384: $18-26$

10. Bacus SS, Gudkov AV, Esteva FJ, Yarden Y: Expression of erbB receptors and their ligands in breast cancer: Implications to biological behavior and therapeutic response. Breast Dis 1999, I I:63-75.

1I. Borresen-Dale AL: TP53 and breast cancer. Hum Mutat 2003, 21:292-300.

12. Colditz GA, Rosner BA, Chen WY, Holmes MD, Hankinson SE: Risk Factors for Breast Cancer According to Estrogen and Progesterone Receptor Status. I Nat/ Cancer Inst 2004, 96:2 I 8-228.

13. Slamon DJ, Clark GM, Wong SG, Levin WJ, Ullrich A, McGuire WL: Human breast cancer: correlation of relapse and survival with amplification of the HER-2/neu oncogene. Science 1987, 235: 177-182.

14. Demonty G, Bernard-Marty C, Puglisi F, Mancini I, Piccart M: Progress and new standards of care in the management of HER-2 positive breast cancer. Eur J Cancer 2007, 43:497-509.
15. Suo Z, Daehli KU, Lindboe CF, Borgen E, Bassarova A, Nesland JM: Real-time PCR quantification of c-erbB-2 gene is an alternative for FISH in the clinical management of breast carcinoma patients. Int / Surg Pathol 2004, I 2:3 | I-3 I8.

16. Raab G, Hoegel B, Biebl J, Eiermann W: Chromogen in situ hybridisation (CISH) for HER2 assessment is highly concordant with FISH in core cut biopsies of primary T2 breast cancers. J Clin Oncol 2004, 22: 14.

17. Tsuda H: HER-2 (c-erbB-2) test update: present status and problems. Breast Cancer 2006, 13:236-248.

18. Viani GA, Afonso SL, Stefano EJ, De Fendi LI, Soares FV: Adjuvant trastuzumab in the treatment of her-2-positive early breast cancer: a meta-analysis of published randomized trials. $B M C$ Cancer 2007, 7:153.

19. Mass RD, Press MF, Anderson S, Cobleigh MA, Vogel CL, Dybdal N Leiberman G, Slamon DJ: Evaluation of clinical outcomes according to HER2 detection by fluorescence in situ hybridization in women with metastatic breast cancer treated with trastuzumab. Clin Breast Cancer 2005, 6:240-246.

20. Ross JS, Fletcher JA, Bloom KJ, Linette GP, Stec J, Clark E, Ayers M, Symmans WF, Pusztai L, Hortobagyi GN: HER-2/neu testing in breast cancer. Am J Clin Pathol 2003, I 20(Suppl):S53-S7I.

21. Yaziji $H$, Goldstein LC, Barry TS, Werling R, Hwang $H$, Ellis GK, Gralow JR, Livingston RB, Gown AM: HER-2 testing in breast cancer using parallel tissue-based methods. JAMA 2004, 291:1972-1977.

22. Vera-Román JM, Rubino-Martínez LA: Comparative assays for the HER-2/neu oncogene status in breast cancer. Arch Pathol Lab Med 2004, I 28:627-633.

23. Choi DH, Shin DB, Lee MH, Lee DW, Dhandapani D, Carter D, King BL, Haffty BG: A comparison of five immunohistochemical biomarkers and HER-2/neu gene amplification by fluorescence in situ hybridization in white and Korean patients with early-onset breast carcinoma. Cancer 2003, 98: 1587-1595.

24. Carlson RW, Moench SJ, Hammond ME, Perez EA, Burstein HJ, Allred DC, Vogel CL, Goldstein LJ, Somlo G, Gradishar WJ, Hudis CA, Jahanzeb M, Stark A, Wolff AC, Press MF, Winer EP, Paik S, Ljung BM, NCCN HER2 Testing in Breast Cancer Task Force: HER2 testing in breast cancer: NCCN task force report and recommendations. I Natl Compr Canc Netw 2006, 4 Suppl 3:SI-S22.

25. Haines GK 3rd, Wiley E, Susnik B, Apple SK, Frkovic-Grazio S, Reyes C, Goldstein LC, Dadmanesh F, Gown AM, Nadji M, Bracko M, Tavassoli FA: HER2 in well differentiated breast cancer: is testing necessary? Breast Cancer Res Treat 2008 in press.

26. Cordon-Cardo C, Dalbagni G, Saez GT, Oliva MR, Zhang ZF, Rosai J, Reuter VE, Pellicer A: p53 mutations in human bladder cancer: genotypic versus phenotypic patterns. Int J Cancer 1994, 56:347-353.

27. Colomer R, Montero S, Lluch A, Ojeda B, Barnadas A, Casado A, Massutí $B$, Cortés-Funes $\mathrm{H}$, Lloveras $\mathrm{B}$ : Circulating HER2 extracellular domain and resistance to chemotherapy in advanced breast cancer. Clin Cancer Res 2000, 6:2356-2362.

28. Lebeau A, Deimling D, Kaltz C, Sendelhofert A, Iff A, Luthardt B, Untch M, Löhrs U: HER-2/neu analysis in archival tissue samples of human breast cancer: comparison of immunohistochemistry and fluorescence in situ hybridization. J Clin Oncol 200I, 19:354-363.

29. Wolff AC, Hammond ME, Schwartz JN, Hagerty KL, Allred DC, Cote RJ, Dowsett M, Fitzgibbons PL, Hanna WM, Langer A, McShane LM, Paik S, Pegram MD, Perez EA, Press MF, Rhodes A, Sturgeon C, Taube SE, Tubbs R, Vance GH, Vijver M van de, Wheeler TM, Hayes DF, American Society of Clinical Oncology; College of American Pathologists: American Society of Clinical Oncology/College of American Pathologists guideline recommendations for human epidermal growth factor receptor 2 testing in breast cancer. J Clin Oncol 2007, 25: I I8-145.

30. Perez EA, Suman VJ, Davidson NE, Martino S, Kaufman PA, Lingle WL, Flynn PJ, Ingle JN, Visscher D, Jenkins RB: HER2 testing by local, central, and reference laboratories in specimens from the North Central Cancer Treatment Group N983 I intergroup adjuvant trial. J Clin Oncol 2006, 24:3032-3038.

31. Santinelli A, Baccarini M, Colanzi P, Stramazzotti D, Fabris G: Immunohistochemical evaluation of HER-2/neu expression in infiltrating breast carcinoma: a study of reproducibility. Anal Quant Cytol Histol 2002, 24:54-62. 


\section{Pre-publication history}

The pre-publication history for this paper can be accessed here:

http://www.biomedcentral.com/1471-2407/9/51/prepub

Publish with Bio Med Central and every scientist can read your work free of charge

"BioMed Central will be the most significant development for disseminating the results of biomedical research in our lifetime. " Sir Paul Nurse, Cancer Research UK

Your research papers will be:

- available free of charge to the entire biomedical community

- peer reviewed and published immediately upon acceptance

- cited in PubMed and archived on PubMed Central

- yours - you keep the copyright

Submit your manuscript here:

http://www.biomedcentral.com/info/publishing_adv.asp 